his life doing the same job. Perhaps so, but it would have been good to have had evidence of an engineer who had, say, reached the board of his company. Second, computer technology is entirely ignored, probably because there was until recently no national body to represent it. Some of the National Computing Centre's boundless enthusiasm would have been well employed in devising an exhibit.

The exhibition will, of course, only be seen by children from the Home Counties, who are already privileged by comparison with those from areas with no museum of science and technology. The possibility of the exhibition touring the country is being pursued by the ministry, but with no great enthusiasm. Every engineer has his day, it seems, but especially if he lives in the south-east.

\section{Tug on the Purse Strings}

PuBLIC spending on science in the United States seems now to have reached the plateau advertised by discussions earlier this year in Congress. According to a survey carried out by the National Science Foundation (Federal Funds for Research, Development and Other Scientific Activities, NSF 66-25, U.S. Government Printing Office, $\$ 1.25)$, government expenditure on research and development in the current fiscal year (from July 1, 1966) will not exceed that in the previous year. Since 1964, the rate of increase of this expenditure has been a mere 3 per cent a year, which is less than a third of the rate of growth between 1956 and 1964. These figures do not, however, imply that there has been an abrupt halt throughout the field. Indeed, the plateau is a consequence of the curtailment of the development expenditure of the three United States agencies which between them dispose of 85 per cent of all federal money for research and development - the Department of Defense, the Atomic Energy Commission and the National Aeronautics and Space Administration. Other agencies of the United States Government are being involved in research and development on a growing scale. What is called basic researchsome of it supported by the three big spending agencies -also continues to prosper, with a growth rate of 11 per cent a year in the three years to June 30, 1967. This is a healthy state of affairs by most standards except by those established in the United States in the late fifties, when public expenditure on basic research increased by roughly 29 per cent a year.

Public expenditure in the current year is expected to be $\$ 15,900$ million, which is the estimated total for the fiscal year ending in June. In addition, $\$ 700$ million will be spent on capital equipment of various kinds (compared with $\$ 1,100$ million last year). The scale of all this is vividly shown by the fact that in the year to June 1966, research and development took 15 per cent of all the funds available to the United States Government-a proportion which has increased ten-fold since 1946, when Federal spending on research and development was a mere $\$ 900$ million, or rather less than what will be spent on medical research alone in the current financial year.

The decline in the importance of the big spending agencies has been dramatic. As recently as 1960 , the Department of Defense spent 72 per cent of all the federal money for research and development; now NASA is a close second, with 32 per cent (compared with 44 per cent for Defense). At the same time, the spending of the Departmeat of Health, Education and Welfare is growing with such vigour that it promises soon to overtake the AEC as the third biggest sponsor of research and development. Between 1960 and 1966 this department multiplied the scale of its effort three times, and is expected to spend $\$ 1,271$ million in the current financial year. Other booming sectors in research and development are the social sciences, where the pace of growth has amounted to 27 per cent a year for the last decade, and the handling of scientific: and technical information, on which the United States Government plans to spend a total of $\$ 273$ million in the current financial year.

\section{More Ind ustrial Research}

IN the first three years of this decade, industrial com. panies in the United States increased their expenditure on research and development more rapidly than it grew by government contracts for research and development. This is clear from the survey by the National Science Foundation of spending on industrial research and development in 1963 (Basic Research, Applied Research and Development in Industry, 1963, NSF 66-15, Government Printing Office, \$1).

Industrial companies spent 73 per cent of all the funds available in the United States for research and development in 1963, and employed 70 per cent of all qualified scientists and engineers. Their total expenditure was $\$ 12,700$ million, an increase of 11 per cent compared with the previous year. Federal funds accounted for 57 per cent of the industrial budget, or for a total of $\$ 7,300$ million. Altogether, the value of government contracts for research and development let with American industry increased fourfold in the decade to 1963 , chiefly as a result of the activities of the Department of Defense and NASA.

Because of the recent interest in the equitable geographical distribution of government expenditure in the United States, the report predictably has much to say on this matter. California emerges as the state in which most industrial research and development is carried out; in 1963 the total value of industrial development there was $\$ 3,500$ million, of which $\$ 3,000$ million came from federal contracts, mostly in defence and space developments. The report shows that in 1963 the southern states were the most neglected - one of the reasons why many of the large and expensive facilities for space development have been built in the southern United States in recent years.

of the skilled manpower available to industry, estimated to amount to 348,000 in 1963 , the aircraft and missile industries employed by far the greatest number (117,000, or 31 per cent). Electrical equipment and communications used 22 per cent of the skilled manpower, and the chemical industry 11 per cent. The survey showed that scientists and engineers were most prolifically employed in those branches of industry in which federal funds were most lavishly available. The larger companies employed proportionately more skilled peoplean average of 29 full-time scientists and engineers in every 1,000 employees or an increase of 35 per cent since 1958. There is nothing in the report to show whether the positive correlation between the employment of scientists and the size of companies is a proof that science brings prosperity; it may, of course, be that larger companies are more able to afford the luxury. 